\title{
Recognising stressors and managing stress in Bulawayo Metropolitan Province primary schools
}

\begin{tabular}{|c|c|}
\hline \multicolumn{2}{|c|}{$\begin{array}{l}\text { Author: } \\
\text { Victor C. Ngwenya }{ }^{1,2}\end{array}$} \\
\hline \multicolumn{2}{|c|}{$\begin{array}{l}\text { Affiliations: } \\
{ }^{1} \text { Department of Economic } \\
\text { and Management Sciences, } \\
\text { College of Economic and } \\
\text { Management Sciences, } \\
\text { University of South Africa, } \\
\text { Pretoria, South Africa }\end{array}$} \\
\hline \multicolumn{2}{|c|}{$\begin{array}{l}{ }^{2} \text { Department of Educational } \\
\text { Management and Leadership, } \\
\text { Faculty of Education and Arts, } \\
\text { Zimbabwe Open University, } \\
\text { Bulawayo, Zimbabwe }\end{array}$} \\
\hline \multicolumn{2}{|c|}{$\begin{array}{l}\text { Corresponding author: } \\
\text { Victor Ngwenya, } \\
\text { victor.ngwenya@gmail.com }\end{array}$} \\
\hline \multicolumn{2}{|c|}{$\begin{array}{l}\text { Dates: } \\
\text { Received: } 17 \text { Jan. } 2021 \\
\text { Accepted: } 24 \text { Aug. } 2021 \\
\text { Published: } 30 \text { Nov. } 2021\end{array}$} \\
\hline \multicolumn{2}{|c|}{$\begin{array}{l}\text { How to cite this article: } \\
\text { Ngwenya, V.C. (2021). } \\
\text { Recognising stressors and } \\
\text { managing stress in Bulawayo } \\
\text { Metropolitan Province } \\
\text { primary schools. SA Journal } \\
\text { of Human Resource } \\
\text { Management/SA Tydskrif vir } \\
\text { Menslikehulpbronbestuur, } \\
\text { 19(0), a1549. https://doi. } \\
\text { org/10.4102/sajhrm. } \\
\text { v19i0.1549 }\end{array}$} \\
\hline \multicolumn{2}{|c|}{$\begin{array}{l}\text { Copyright: } \\
\text { ( 2021. The Authors. } \\
\text { Licensee: AOSIS. This worl } \\
\text { is licensed under the } \\
\text { Creative Commons } \\
\text { Attribution License. }\end{array}$} \\
\hline \multicolumn{2}{|l|}{ Read online: } \\
\hline 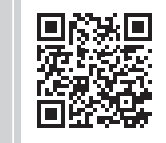 & $\begin{array}{l}\text { Scan this QR } \\
\text { code with your } \\
\text { smart phone or } \\
\text { mobile device } \\
\text { to read online. }\end{array}$ \\
\hline
\end{tabular}

Orientation: Knowledge of work-related stressors which trigger an avalanche of stress-related illnesses is crucial if teachers are to successfully manage stressful situations in their workplaces.

Research purpose: The purpose of this research study was to gain a deeper understanding of the potential causes of stress in primary schools with the intention of suggesting coping strategies to deal with it.

Motivation of the study: Teachers who were successful in managing stressful situations in their workplaces were able to enhance their creativity, productivity, efficiency and effectiveness, consequentially the organisation and learners being the net beneficiaries.

Research approach/design and method: Post-positivism informed the quantitative approach employed. A cross-sectional survey design utilising a standardised questionnaire was used to collect data from 87 qualified and experienced teachers who were systematically sampled. The concept of stress was examined first followed by the identification of stressors. Resultantly, coping strategies to remedy stressful situations experienced were proffered.

Main results: The study revealed that primary school teachers were conscious of what stress entails, its consequences for themselves and the organisation, the potential stressors which were likely to hinder their job performance or cause stress related illnesses, and ways of dealing with them.

Practical and management implications: Participative management was suggested when engaging teachers in job-related decisions so as to avoid overloading them beyond their expectations and capacities to avert stressful encounters.

Contribution/value-add: The teachers' knowledge of how negative stressors reduce their production levels at their workplaces enables them to develop coping strategies to deal with the stressors head-on.

Keywords: distress; exhaustion; General Adaptation Syndrome; relaxation stress; stress management.

\section{Introduction}

The advent of modern life, influenced by the events of the industrial revolution, ushered in job-related stress in schools and has the potential of reducing staff efficiency and effectiveness (Haokip \& Latha, 2018; Rosch, 2017). Worldwide, the unfavourable working conditions prevailing in the teaching profession caused by the socio-economic ills of the times (Ngwenya, 2021), have resulted in teachers experiencing stressful conditions in one way or another. Although chronic stress may be dangerous to one's health if not managed properly, acute stress motivates teachers to focus on the task or act to solve the task (Legg, 2020; Tran et al., 2020). The motivating effects of positive stress on teachers makes its presence in organisations inevitable. It is not surprising that contemporary researchers have dubbed stress the 'illness of the century' as its presence enhances the creativity and productivity levels of teachers (Panigrahi, 2017, p. 154). To that end, the absence of stress would make life a dull endeavour which would be not worthy living at all (Schmidt \& Chen, 2021). Since negative stress has physical, cognitive, physiological, psychological and emotional effects on teachers, which in turn will affect the educative enterprise with the net sufferers being learners, the purpose of this study, therefore, is to enable teachers recognise negative stressors in schools at their infancy if stress is to be successfully managed (Tran et al., 2020). 


\section{Orientation}

Teaching is one of the most stressful professions worldwide, which of late has been aggravated by the outbreak of the coronavirus; in the current state of African economies, stress has become a matter of contention (Schmidt \& Chen, 2021). Consequently, the presence of negative stressors in an individual may cause alarm and confusion, and reactions to it may be different as people are biologically wired differently (Legg, 2020). Some may withstand stressful situations while others may breakdown (Haokip \& Latha, 2018). The pleasant and unpleasant stress teachers experience in their workplaces may best be described using Lazarus' Transactional Theory of stress which identified them as eustress and distress, respectively (Cohen, Murphy, \& Prather, 2019). Eustress demands are seen as psychological and physical opportunities for learning, growth and achievement (Cohen et al., 2019). Resultantly, time pressure, work complexity and work responsibility fulfil the human need for self-esteem and self-actualisation (Cohen et al., 2019). This accomplishment leads to relaxation and satisfaction, necessary ingredients for healthy and productive work (Addison \& Yankyera, 2015). Taking this into consideration, if eustress is carefully managed in schools, goal attainment may be enhanced (Cohen et al., 2019). All that might be needed, perhaps, is to assign such tasks to the teachers which are within their capabilities, thereby making them excel. Goal accomplishment would make them feel relaxed but when demands of the task exceed expectations and capabilities, relaxation turns into exhaustion and satisfaction turns into distress (Legg, 2020).

Distress may not only cause physical, mental and behavioural problems in the workplace which may be detrimental to the goals, ethos, values and norms of the organisation, but fatalities too (Cohen et al., 2019; James \& Sidin, 2017). Some distressful effects include: inability to pay attention to work, drug and alcohol abuse, and harmful behaviour to self or others, hence compromising the effectiveness and efficiency of the individual and the organisation (The American Institute of Stress, 2020). Comforting though is that teachers may be trained to recognise negative stressors in their workplaces and manage them (Panigrahi, 2017). All that teachers need is to identify the stressors early on before they become disastrous so that they can be in a position to remedy and overcome them (Legg, 2020). However, of noteworthy in this context is that distress is not an illness but creates a state which when it becomes excessive and prolonged, may develop into a physical and mental illness, hence the need to manage it using various coping strategies (Tan \& Yip, 2018).

Selye (1936), pioneered a study which eloquently explained the General Adaptation Syndrome (GAS) model, based on physiology and psychology. His study revealed that every event that threatens the well-being of an organism (i.e. a stressor) leads to a three-stage bodily response, namely: (1) alarm stage reaction, (2) resistance or adaptation stage, and (3) exhaustion stage, as detailed below.

\section{Alarm reaction stage}

The body upon perceiving a stressor is activated into 'fightor-flight' response and the sympathetic nervous system is stimulated as its resources are mobilised to encounter the threat or danger (Lucile, 2016). The heart beats faster sending blood to the arms or legs in case one needs to fight or flee. This response to a threatening situation is biologically programmed (Legg, 2020). During this stage, the brain sends an emergency signal to the other parts of the body, which lets those parts know, that one is in a dangerous situation (Legg, 2017). As the body mobilises itself to react, one can choose either a 'fight or flight' response to which the nervous system will be programmed (Legg, 2017). This kind of reaction to stress serves as the body's defence mechanism (Saini, 2016).

\section{Resistance or adaptation stage}

If the alarm stage does not help one escape from a stressful situation, the body progresses to the next stage, where one remains in an alert stage for a longer time (Panigrahi, 2017). During the resistance stage, the body resists and compensates as the parasympathetic nervous system attempts to return many physiological functions to their pre-stress levels, while the body focuses the resources against the stressor and remains on red alert (Lucile, 2016). Prolonged stressful conditions without relaxation and rest may make the body prone to fatigue, lack of concentration, irritability and lethargy, which are all symptoms of negative stress (Higuera \& Legg, 2017; Saini, 2016). Teachers need to guard against these negative developments in their bodies.

\section{Exhaustion stage}

If the stressor continues beyond the body's capacity, the resources will become exhausted and it will be susceptible to disease and death (Lucile, 2016). The stressed person may give up or feel that the situation is hopeless (Panigrahi, 2017). Signs of exhaustion may include: fatigue, depression, burnout, anxiety and decreased stress tolerance (Higuera \& Legg, 2017).

Teacher burnout in this context refers to 'a state of mental, physical and emotional exhaustion, usually resulting from chronic and persistent stress' (Saini, 2016, p. 99). By the same token, Selye (1936) observed that, when one is in such a state, the immune system is weakened and the body is put at risk of stress-related illnesses. Resultantly, prolonged stress of this magnitude would lead to physical and psychological disorders such as hypertension, heart-related diseases, sleep disturbances, back pains and ulcers (The American Institute of Stress, 2020). Furthermore, at a personal level, relationships with family and friend may also be disturbed (Legg, 2020).

Knowledge of the GAS model enables teachers to recognise chronic stressors in their workplaces which resolve themselves by being ignored and those which need confrontation. Both approaches prevent stressors from developing into prolonged 
stress which may lead to exhaustion and numerous stressrelated illnesses.

\section{Motivation of the study}

Besides stress having a negative impact on the retention and recruitment of teachers and their health and working conditions, where it manifests itself, it must be sufficiently managed in order to reduce absenteeism, depression, mental illness so as to improve health, happiness and effectiveness of teachers at work (Tran et al., 2020). Most importantly, teachers must guard against negative stress which disturbs their physical and mental capabilities in their workplaces (Haokip \& Latha, 2018).

To that end, a Nigerian study on stress revealed that teachers at their workplaces are stressed by factors such as long working hours, heavy workload, pressure to complete a given task within a short period of time, sudden changes in the workplace and society, lack of skills to do the job, discrimination and harassment among several others (Haokip \& Latha, 2018). In corroboration, Pelser and Van Wyke's (2016) South African study added the following potential stressors at workplaces: new curricula, teacher shortages, teachers who are burdened with having to make a variety of modifications in their personal and professional lives.

Likewise, the socialist ideology adopted by the Zimbabwean government in 1980, which was mainly driven by 'growth with equity', ushered in stressful radical curriculum reforms in the education sector as attempts were being sought to redress the social inequalities and imbalances caused by the past colonial policies (Sibanda \& Young, 2020). Racialism was abolished and primary education was universalised though without regulatory enforcement, which increased the admission rates to stressful levels (Government of Zimbabwe [GoZ], 2020; Ngwenya, 2021). The political and ideological changes undertaken in the education sector resulted in a high teacher/learner ratio, overcrowding, inadequacy of infrastructure which led to double session (i.e. hot seating), shortages of teachers, as well as learning and teaching materials(Ngwenya, 2021).

Ngwenya's (2020) study, conducted after the introduction of a new competence-based curriculum in 2015 on the recommendations of the Nziramasanga's 1999 Commission, furthermore confirmed the existence of similar stressors in the teaching fraternity. In addition to the stressors enumerated above, teachers were found to be stressed by the congested timetable, the introduction of new learning areas which deskilled them, the emphasis on science, technology, engineering and mathematics (STEM) subjects (GoZ, 2015) amidst a shortage of teaching and learning resources which was further aggravated by the incapacitation of the parents to pay fees because of the unpredictable hyper-inflationary environment. Besides that, the mainstreaming of the Early Childhood Development (ECD) classes to the regular school also increased overcrowding. Such job duties and working conditions which are beyond the person's capabilities create anxiety and tension which are symptoms of stress (Haokip \& Latha, 2018).

In adherence to its socialist path, the Zimbabwean government further introduced the philosophy of 'Education with Production' which was crafted along the MarxistLeninist ideological concept of 'polytechnic education', and Paulo Freire's ideas concerning the dialectic of knowledge and practice (Kanyongo, 2005; Shizha \& Kariwo, 2011). This was meant to marry theory and practice across the curriculum. Vocational subjects had to be introduced and teaching pedagogy had to be tailor-made in sync with the philosophy which government had adopted. Towards that end, childcentred and democratic teaching methods which focused on collectivism were encouraged as opposed to individualism; learners were grouped according to abilities so as to accommodate their individual differences in the planning of teaching and learning activities (Kanyongo, 2005). Such changes were stressful for the already overburdened classroom practitioner. Also, the experienced teachers needed re-orientation so as to familiarise them with the new strategies of teaching and philosophy.

This radical paradigm shift in pedagogical requirements deskilled and further stressed Zimbabwean primary teachers. Moreover, the lack of relevant training programmes affected the school's performance and retention rate which also had a bearing on teachers' satisfaction levels at their workplaces as alluded to earlier by Haokip and Latha (2018). Given such a scenario, stress management at workplaces becomes an inevitable component in the development of the ideal teacher.

Arguably, the technological changes which seem to be occurring minutely in the teaching profession with Zimbabwe introducing a new competence-based curriculum with an information communication technological (ICT) bias, results in teachers feeling physically and emotionally disabled as they are unable to keep abreast with such developments (GoZ, 2015). Teachers are warned to brace up for similar changes which will be prevalent for the next decade or so as new jobs will emerge which will increase the risk of psychological disorders (Legg, 2020; Tran et al., 2020). The situation becomes increasingly unpredictable for the employed women, whose multiple role demands (i.e. parenting status, household chores and job commitment) and constrained economic opportunities may put them at high risk for psychological disorders and job displacements, along with the advent of computers and robots in workplaces (Addison \& Yankyera, 2015). The same authors further observed that women as a group experience completely different stress from that of men. They have been found to easily succumb to psychological stress involving depression and emotional discomfort, while men are prone to coronary cardiovascular disease and liver cirrhosis. However, despite the weakness, women have been found to manage stressful conditions far better than men (Addison \& Yankyera, 2015). 
Since teaching in many African countries is rated to be among one of the low-paying jobs, teachers have been found to be a high risk group when confronted with stressful situations. Judging by the low remuneration which they receive, they seem to be annoyed by excitement and a person's talents or a worker's resources and needs (Haokip \& Latha, 2018).

Various studies conducted in African countries have revealed that many teachers were found working under negative stressful conditions which led to emotional breakdown, burnout and distress (Tran et al., 2020). The latter state is confirmed by a recent Zimbabwean study which was conducted by the Friendship Bench Services, African Mental Health Research Initiative which revealed that more than 100000 people sought help on depression and anxiety (Zvanyanya, 2020). The study further revealed that more people would be prone to mental illness in the future, and the situation would be further compounded by the fact that most African countries, Zimbabwe included, do not have the capacity to deal with such a surge as guidance and counselling services and mental hospitals were limited. Suicidal cases committed by Zimbabwean teachers over welfare issues and depression as widely reported in the print media confirms the scarcity of such services (Dube, 2020).

Weighing in are worldwide researches which have revealed that teachers as individuals are stressed differently in their workplaces depending on their cultural backgrounds and gender (Tran et al., 2020). While some have been found to be stressed by failure to accomplish an allocated task, worse still if it is beyond their capabilities, others have been found to be stressed by competition depending on whether it is physical or emotional (Saini, 2016). Teachers competing to complete given tasks either as individuals or as a group can either be healthy or unhealthy to one's well-being (Legg, 2020). On a positive note, competition may create energy for a person to learn new duties and skills; whereas on the negative side, if the daily requirements cannot be overcome, it may result in exhaustion which is equally stressful (Saini, 2016). To make matters worse, the hierarchical structure of the school has also been found to be stressful to subordinates when rigidly adhered to (Saini, 2016). Moreover, education managers in their attempt to control and increase productivity in the organisation sometimes use fear and stress (Tran et al., 2020).

Arguably under such circumstances, stress seems to cause physical, mental and behavioural problems which affect one's capabilities to perform his or her job and will in turn affect the productivity levels of the organisation if not successfully managed (Tran et al., 2020). More so that in its extremity it may lead to distress, a mental or psychological condition which is harmful and can be fatal (Haokip \& Latha, 2018). As noted above, stress can be disastrous for an individual or organisation; negative stress and its consequences however, can be prevented by training teachers effectively for better recognition and management of stress factors through appropriate coping strategies (Mujtaba, Cavico, \& Senathip, 2020).

\section{Objectives of the study}

The objectives of the study are as follows:

- To discover the major causes of stress among primary teachers teaching in Zimbabwean schools and highlight their consequences.

- To explore various ways Zimbabwean primary teachers may manage stressful conditions utilising various coping strategies with the intent of either minimising or eliminating stressful behaviours at their workplaces.

\section{Literature review}

Since stress is a universal phenomenon and affects individuals in their daily lives differently, researchers also define it differently depending on its physiological and psychological impact on the individual or organisation (Legg, 2020).

According to the National Institute for Occupational Safety and Health (NIOSH, 2014, para. 10) stress may be defined as 'the harmful physical and emotional responses that occur when the requirements of the job do not match the capabilities, resources or needs of the worker'. In the same vein, Jayashree (as cited in Gulati \& Parashar, 2016, p. 98) perceived it as 'caused when a person is subjected to extreme expectations, unusual situations, pressures or demands that are difficult to handle'. Such physical, emotional or mental pressures experienced by an individual create anxiety and tension which may lead to burnout (Tran et al., 2020). Addison and Yankyera (2015) and Legg (2020) go further to elaborate that stress may be from the environment, psychological or social situations or illness or a medical procedure. In the teaching arena, when too much pressure is exerted on teachers to meet certain demands or deadlines in an unfavourable environment with limited resources regardless of their needs and capacities may result in stress (Tran et al., 2020). Teachers, like machines, can also breakdown if job expectations are beyond their capabilities (Saini, 2016).

\section{The major sources of stress in workplaces}

As individuals and organisations experience stress differently, stressors discussed in this study are not exhaustive. Therefore, the major sources of stress identified in this study have conveniently been divided into three categories, namely; life events, personal and organisational/ work-related factors.

\section{Life events and personal factors}

Life events could be any event or events that disrupt a person's attitudes, emotions or behaviours, and may end up in a life trauma such as financial difficulties, marital problems, sudden physical illness or the death of a beloved one (Cohen 
et al., 2019; Legg, 2020). On the other hand, personal factors in this context would refer to stress which affects people in different ways determined by their personalities which are identified as two categories - Type A and Type B (Saini, 2016; Tran et al., 2020). James and Sidin (2017) posited that Type A people are always energetic; they have a strong sense of urgency, a high need for power, are often obsessed with their work, and are extremely competitive. They want to get things done and will do almost everything to achieve their goals. They often get aggressive, impatient and irritable if people interfere with their work and are easily affected by responsibilities. On the contrary, Type B people work at a steady and relaxed pace, dislike hostility, feel more confident about their work and are less anxious about time and colleagues, making them the opposite of Type A (James \& Sidin, 2017). James and Sidin further stated that both personalities are present in an individual with one of them being dominant. In this study, it is the Type A personality traits which the teachers must be concerned about, because such traits may lead to burnout or severe health problems such as heart attacks.

\section{Organisational and work-related stress}

Career concerns such as threats and intimidation may make workers feel insecure in their jobs (Panigrahi, 2017). Setting deadlines on tasks which are beyond their capabilities are equally stressful (Ngwenya, 2020). Most importantly, the lack of opportunity for growth and rapid changes for which workers are unprepared may aggravate stress (GoZ, 2015; Haokip \& Latha, 2018; Pelser \& Van Wyke, 2016). Factors related to the design of the task which can be stressful include: heavy workload, infrequent rest breaks, long working hours and shift work, and routine tasks that have inherent learning (Legg, 2020; Ngwenya, 2020). Similarly are the role demands of the teachers that require them to have a good rapport with the learners during the teaching and learning enterprise, at the same time evaluating their performance and disciplining them which may cause a role conflict - a situation that demands 'a simultaneous occurrence of two (or more than two) groups of pressures such that compliance with one would make more difficult compliance with the other' (Gulati \& Parashar, 2016, p. 99). In the same vein, conflicting expectations and too many 'hats to wear' may result in role ambiguity (Legg, 2020), Role ambiguity being 'a degree of vagueness ... or un clarity in desired expectations that creates difficulties for a person to fulfil requirements' (Gulati \& Parashar, 2016, p. 99).

Likewise when policy formulation and decision-making is the preserve of top management, teachers may resist them triggering perpetual stressful conflicts in schools (Gulati \& Parashar, 2016; Health and Safety Executive, 2020; Tran et al., 2020). Such a scenario may be worsened by the interpersonal demands of an individual group. Group members wanting to conform to expected or prescribed group norms and values regardless of their capabilities may be overstretched (Satpathy \& Mitra, 2015). Moreover, if such expectations are not applied consistently and equitably may result in personality clashes (Tran et al., 2020). Stressful for female workers would also be male chauvinists who would stereotype them because of their feminine prejudices (Addison \& Yankyera, 2015). Above all are interpersonal relationships which may prevail between teachers and top management. If teachers feel that their efforts are not being recognised or appreciated by the top management, such relationships may be counterproductive. Such negative forces would further be compounded if teachers felt that top management was ill-treating them and was not supportive of their work endeavours (Health and Safety Executive, 2020). In the same way, crowded classrooms or economic problems emanating from the physical and psychological environment teachers found themselves operating in would also be stressful (Ngwenya, 2021; Tran et al., 2020).

\section{Management of stress in the workplace}

Researchers are in agreement that before teachers think of intervention strategies to employ to manage stress, the size of the organisation and availability of resources to implement whatever strategy needs execution must be considered (Haokip \& Latha, 2018; Juneja, 2015). Teachers must be made to understand their working conditions (Ngwenya, 2021), stress levels, health and satisfaction, if they are to be able to recognise stressful conditions in their workplaces (Haokip \& Latha, 2018; Juneja, 2015). Haokip and Latha (2018) further posited that at the micro level, official discussions of preventive strategies may suffice. Whereas at a macro level, processes to combat stress need to be put in place. Towards this direction, stress may be dealt with at either individual or organisational level (Panigrahi, 2017). Noteworthy in this context is that stress management strategies are 'not one-size-fits-all'. Teachers are encouraged to experiment and find out what works in their organisations first prior to implementation (Legg, 2020).

\section{Individual strategies}

At an individual level, teachers may belong to trustworthy support groups involving the significant others or colleagues to lean against when in dire need of assistance. Sharing problems or doing favours for each other within such groups, does not only boost one's confidence levels but strengthens the relationship as well (Health and Safety Executive, 2020; Tran et al., 2020). Apart from that, teachers must develop the habit of having prioritised list of tasks to be executed daily as part of their time management training (Kaizen Business Coaching, 2021; Legg, 2020). This would enable them to execute their tasks productively without trying to impress their supervisors (Gulati \& Parashar, 2016). However, where roles are conflicting and ambiguous, they should not hesitate to seek clarification from the management (Juneja, 2015; Legg, 2020). Alternatively, when confronted with such a stressful situation one can either confront it or leave it (Lucile, 2016; Saini, 2016). Confrontation to resolve role ambiguity may sometimes lead to workable solutions and declining 
promotion when roles conflict may reduce stress as well. Besides that, teachers may minimise stressful situations by engaging in various physical exercises. Exercise diverts minds from the pressures of work, boosts self-confidence and optimism, increases the body's blood circulation and thus keeping one fit too (Legg, 2020). Balancing work and play in the workplace augurs well with Legg's (2020, p. 7) assertion that 'All work and no play is a recipe for burnout'; cracking jokes during such sessions has been found to spice up the occasion as well (Tran et al., 2020).

Furthermore, teachers may be encouraged to be optimistic when confronted with challenges of whatever magnitude in their attempt to cope with stress. To achieve optimal performance in such a scenario, they must be assigned realistic goals, be stimulated towards achieving them, and be given constant feedback in the process (Tran et al., 2020). This can only be achieved if the distribution of the incentive system is equally fair and just. Although at a personal level, teachers might be driven to achieve set targets, this must not compromise on their family, health, peers and social life (Juneja, 2015; Legg, 2020). In the process, those portraying symptoms of stress-related illnesses should be encouraged to find solace in prayer and meditation (Addison \& Yankyera, 2015; Tran et al., 2020). Optionally, a vacation would relax and revitalise them (Legg, 2020; Tran et al., 2020).

By the same token, studies by Haokip and Latha (2018), Legg (2020) and Tran et al. (2020) proposed the utilisation of the following method to evoke the relaxation response in an individual:

1. Sit quietly in a comfortable position.

2. Close your eyes.

3. Deeply relax all your muscles, beginning at your feet and progressing up to your face. Keep them relaxed.

4. Breathe in and out through your nose and be aware of your breathing by saying a word at each instance such as 'one'.

5. Continue for $20 \mathrm{~min}$. You may open your eyes to check on time but do not use an alarm clock. When you have finished, sit quietly for some time first with your eyes closed and later with them opened. Wait for a few minutes before standing up.

6. Do not be bothered by quick results and let the relaxation occur at its own space. When distracting thoughts occur, ignore them by not dwelling on them. Replace them with your single word like 'one'.

However, the frequency of the relaxation response method would be determined by the need.

\section{Organisational strategies}

Job enrichment, job rotation, decentralisation, positive reinforcement, participative management, and a just and fair hearing and orientation procedure are some methods which may be used to deal with stress in organisations (Juneja, 2015). Although researchers condemn leaving stress management to individuals, they suggest that organisations may assist staff to deal with stress as described below.

Teachers should be trained to recognise unpleasant emerging situations and then use coping strategies to reduce the resultant stress (Legg, 2020). Such management training should entail: time management, conflict resolution, decisionmaking, and dealing with people (James \& Sidin, 2017). In order for them to know their role expectations, reporting relationships and responsibilities in their workplaces, a role analysis technique must be employed (Addison \& Yankyera, 2015). This would enable them to discover whether they have a Type A personality which might need management (James \& Sidin, 2017; Legg, 2020). Another way of achieving optimum stress levels in an organisation is by sharing responsibilities (Juneja, 2015) and involving teachers in the decision-making process (James \& Sidin, 2017). As studies have revealed that professional women easily succumb to stress compared to men, organisations must have built-in coping strategies such as establishing mentors and developing training programmes to boost their self-confidence and self-awareness (Addison \& Yenkyera, 2015; James \& Sidin, 2017). Above all, teachers who would have undergone some traumatic experience with regard to their career would need to be rehabilitated so that their behaviour is modified through properly constituted guidance and counselling sessions (Juneja, 2015; Panigrahi, 2017).

\section{Research methodology Research approach}

Post-positivism was the underlying philosophical perspective which informed the epistemological methodology utilised to investigate the question: 'How the recognition of stressors aids teachers to manage stress at their workplace'. This feat was achieved by adopting a quantitative approach which measured the objective reality that exists 'out there' in schools on stress management through a meticulously structured questionnaire (Creswell, 2018). In light of this, as a normative researcher, the intention was to reduce the opinions of teachers on stress management into small and discrete set of variables which could be connected to theory on the observed phenomenon and observations that are verifiable and testable using the scientific method empirically (Denzin \& Lincoln, 2013). This was based on the belief that there are theories and laws that govern the causes of stress and its effects on teachers which may be tested deductively and refined or revised or supported using statistical methods in order to understand the ways in which the stressors could be minimised or eliminated (Best \& Khan, 2014).

\section{Research design}

The strategy of inquiry employed to unravel the truth on the causes of stress in schools and its impact as remedies were sought was the cross-sectional survey ( $\mathrm{O}^{\prime}$ Leary, 2014). A survey was considered ideal for this study as large masses of data with a broader spectrum on the phenomenon were sought. Opinions were derived from 
$(n=87)$ systematically selected respondents for the purposes of drawing inferences on its impact (O'Leary, 2014). In that regard, names of teachers at every school were alphabetically arranged and every third name from the list was selected. The sample size represented (29.5\%) of the parent population $(N=295)$, and was considered reliable, valid, accurate, replicable and suitable for the study in terms of cost, time and convenience (McCombes, 2020; Sharma, 2017).

\section{Research participants}

The research respondents were teachers working in primary schools located in one of the five districts of Bulawayo Metropolitan Province (BMP). From a targeted sample of 91 respondents only 87 were returned representing $95 \%$ of the respondents. The majority of the respondents were females $(72 \%)$, showing how the deployment of teachers in BMP urban schools favours women as per government's gender policy. Most of the teachers investigated underwent training after O level $(80 \%)$ and their professional qualifications were varied: Diploma in Education and Bachelor of Education (33\%) apiece, Masters in Education (19\%), and Certificate in Education (15\%). Their teaching experiences revealed that the majority of them had taught for more than 21 years (35\%) with the least having taught for less than 20 years (19\%). Some had taught for less than 15 years $(24 \%)$, while others for 10 years (22\%). Judging by the professional qualifications of the respondents and their varied teaching experiences, the researcher was convinced that valid and reliable data would be collected on the phenomenon under investigation.

\section{Measuring instrument}

The primary instrument used to collect the raw data was a self-designed structured questionnaire consisting of 61 items and was categorised in four sections. Section A inquired about the biographic data of the respondents (q1-5); Section $\mathrm{B}$ explored the concept of stress as revealed by literature surveyed focusing on the difference between eustress and distress (p6-11); Section C looked at stressors comprising life events, personal and organisational/work related factors (q12-38); and Section D suggested remedies to stressful experiences in the workplace based on related literature reviewed and the cited GAS theory cited (q39-61). The tool was standardised and the responses were pre-coded and rated by means of a 5-point Likert-type scale with options ranging from strongly disagree, disagree, agree, strongly agree and undecided as an escape clause (Bissonnette, 2007). However, in reporting the results, the 5-point Likert scale was collated to three categories - negatives to disagree (D), positives to agree (A) and undecided (U) which remained as it were on the instrument. The fixed responses were meant to enhance the response rate of the respondents within the stipulated timeframe, cover a multitude of observations on the phenomenon, and facilitate the statistical analysis of the data collected (Ngwenya \& Pretorius, 2013). To enhance the tool's validity and reliability, it was pilot tested on 10 non-participating respondents and verified by five colleagues. In the process, ambiguity was minimised and clarity was enhanced (Ngwenya \& Pretorius, 2013). The questionnaire was used to gather data which was analysed and used to draw inferences based on the phenomenon under investigation (McCombes, 2020).

\section{Research procedure and ethical considerations}

Permission was initially sought from the Ministry of Primary and Secondary Education (MoPSE). The approval letter was then used to seek permission from the Provincial Education Director (PED) of BMP. Thereafter, clearance was sought using the PED's letter from the District Schools Inspector. Ethics clearance was then sought from the Zimbabwe Open University before fieldwork was conducted. After that schools under investigation were visited, where formal introductions were made before seeking permission to conduct research in the respective schools from various education managers. Thereafter, names of the teachers were sought from education managers from which the respondents were finally selected.

The selected respondents were briefed about the study with regards to its benefits, the psychological discomforts and dangers that would be experienced by participating so as to elicit their informed consent and voluntary participation (Denzin \& Lincoln, 2013). Willing respondents were made to complete consent forms and were also advised that they were free to withdraw from the study at the data collection stage without risking any penalties (Banister, 2007). The structured questionnaires were then distributed and specific instructions were explained. Confidentiality and anonymity were adhered to by not demanding personal and institutional identifiers (Denzin \& Lincoln, 2013). Respondents were further assured that data collected were going to be used for study purposes only and thereafter would be coded, encrypted and stored in the hard drive of the laptop for a period of 5 years before it would be permanently deleted or discarded. They were also promised that results of the study would be made accessible to them at their request (Creswell, 2018). By consensus, the collection date of the completed questionnaire was agreed upon.

\section{Statistical analysis}

Since the analysis methodology was meant to interpret data collected in order to uncover patterns and trends on which inferences would be drawn about the population values, the variables in the data were categorised, frequency tables and descriptive statistics were used to describe each questionnaire item included within each aspect. Analysis of the data was undertaken by a professional statistician using the Statistical Package of Social Sciences (SPSS, version 16).

\section{Ethical considerations}

Ethical clearance was obtained from the Zimbabwe Open University, ZQNSP/1/20. 
TABLE 1: Respondents' perception of the concept of stress $(n=87)$.

\begin{tabular}{|c|c|c|c|c|}
\hline \multirow[t]{2}{*}{ Frequency table } & \multicolumn{3}{|c|}{ Perception rating } & \multirow[t]{2}{*}{ Total } \\
\hline & D & $\mathbf{U}$ & A & \\
\hline \multicolumn{5}{|l|}{ Conceptualisation } \\
\hline \multirow{2}{*}{$\begin{array}{l}\text { Q6. The harmful physical and emotional } \\
\text { responses that occur when the requirements } \\
\text { of the job do not match the capabilities, } \\
\text { resources or needs of the worker. }\end{array}$} & 6 & 1 & 80 & 87 \\
\hline & 7 & 1 & 92 & 100 \\
\hline \multirow{2}{*}{$\begin{array}{l}\text { Q7. Is a mental feeling when job duties are } \\
\text { beyond a person's capabilities? These mental } \\
\text { feelings create anxiety and tension, which are } \\
\text { symptoms of stress. }\end{array}$} & 8 & 0 & 79 & 87 \\
\hline & $9 \dagger$ & 0 & 90 & 100 \\
\hline \multirow{2}{*}{$\begin{array}{l}\text { Q8. Makes me fail to attain my educational } \\
\text { goals effectively. }\end{array}$} & 25 & 8 & 54 & 84 \\
\hline & 28.7 & 9.2 & 62.1 & 100 \\
\hline \multirow{2}{*}{$\begin{array}{l}\text { Q9. Triggers anxiety, depression and anger } \\
\text { in me resulting in role conflict, role ambiguity, } \\
\text { work overload and daily hassles. }\end{array}$} & 12 & 4 & 71 & 87 \\
\hline & 13.8 & 4.6 & 81.6 & 100 \\
\hline \multirow{2}{*}{$\begin{array}{l}\text { Q10. Provides psychological and physical } \\
\text { opportunities for learning, growth and } \\
\text { achievement. }\end{array}$} & 55 & 6 & 26 & 87 \\
\hline & 63.2 & 6.9 & 29.9 & 100 \\
\hline \multirow{2}{*}{$\begin{array}{l}\text { Q11. If it becomes excessive and prolonged, } \\
\text { it may develop into a physical and mental } \\
\text { illness. }\end{array}$} & 8 & 5 & 74 & 87 \\
\hline & 9.2 & 5.7 & 85.1 & 100 \\
\hline
\end{tabular}

$\dagger$, Adjusted to give a summation of $100 \%$.

\section{Results}

The results are discussed under the following headings used to capture the data, namely: the concept of stress, major sources of stress in the workplace, and the management of stress.

\section{Concept of stress}

Table 1 reveals that the majority of respondents seem to be aware that stress causes physical and emotional harm when the requirements of the job do not match the capabilities, resources or needs of the workers (92\%). They further noted the resultant mental feelings which emanate from job duties which are beyond their capabilities (90\%), thus confirming definitions cited in literature by the NIOSH (2014) and Jayashree's (as cited in Gulati \& Parashar, 2016) respectively. Respondents also admitted that its presence, if excessive and prolonged, would develop into physical and mental illness $(85.1 \%)$, triggered anxiety, depression and anger in them resulting in role conflict, ambiguity, work overload and daily hassles (81.6\%), and made them fail to attain their educational goals effectively (62.1\%). However, they contradicted Cohen et al.'s (2019) suggestion that stress provided psychological and physical opportunities for learning, growth and achievement (63.2\%), implying that they are ignorant of the role eustress plays in their workplace.

\section{Sources of stress in the workplace}

As highlighted in the related literature surveyed, stress occurs at three levels, namely; life events, personal and organisational level. However, Table 2 reports only on the first two factors.

Table 2 reveals that the majority of respondents are stressed by events that cause marital problems, financial difficulties and sudden physical illness or the death of their beloved ones (94.3\%), disrupt their attitudes, emotions and behaviours
TABLE 2: Effects of stress on life events and personal factors $(n=87)$.

\begin{tabular}{|c|c|c|c|c|}
\hline \multirow[t]{2}{*}{ Frequency table } & \multicolumn{3}{|c|}{ Perception rating } & \multirow[t]{2}{*}{ Total } \\
\hline & D & $\mathbf{U}$ & A & \\
\hline \multicolumn{5}{|l|}{ Life events such as: } \\
\hline \multirow{2}{*}{$\begin{array}{l}\text { Q12. A person's attitudes, emotions } \\
\text { or behaviours that may end up in a } \\
\text { life trauma can be stressful. }\end{array}$} & 9 & 6 & 72 & 87 \\
\hline & 10.3 & 6.9 & 82.8 & 100 \\
\hline \multirow{2}{*}{$\begin{array}{l}\text { Q13. Marital problems, financial } \\
\text { difficulties, sudden physical illness } \\
\text { or the death of a beloved one can } \\
\text { be stressful. }\end{array}$} & 4 & 1 & 82 & 87 \\
\hline & 4.6 & 1.1 & 94.3 & 100 \\
\hline \multirow{2}{*}{$\begin{array}{l}\text { Q14. Income below the poverty } \\
\text { datum line. }\end{array}$} & 10 & 8 & 69 & 87 \\
\hline & 11.5 & 9.2 & 79.3 & 100 \\
\hline \multicolumn{5}{|l|}{$\begin{array}{l}\text { Personal factors: Stress affects } \\
\text { people who }\end{array}$} \\
\hline \multirow[t]{2}{*}{ Q15. Are always energetic. } & 66 & 8 & 13 & 87 \\
\hline & 75.9 & 9.2 & 14.9 & 100 \\
\hline \multirow[t]{2}{*}{ Q16. Have a strong sense of urgency. } & 33 & 17 & 37 & 87 \\
\hline & 37.9 & $19.6 \dagger$ & 42.5 & 100 \\
\hline \multirow[t]{2}{*}{ Q17. Are power hungry. } & 33 & 9 & 45 & 87 \\
\hline & 37.9 & $10.4 \dagger$ & 51.7 & 100 \\
\hline \multirow[t]{2}{*}{ Q18. Are extremely competitive. } & 24 & 8 & 55 & 87 \\
\hline & 27.6 & 9.2 & 63.2 & 100 \\
\hline \multirow{2}{*}{$\begin{array}{l}\text { Q19. Work steadily and at a } \\
\text { relaxed pace. }\end{array}$} & 59 & 5 & 23 & 87 \\
\hline & 67.8 & $5.8 \dagger$ & 26.4 & 100 \\
\hline \multirow[t]{2}{*}{ Q20. Are hostile. } & 34 & 16 & 37 & 87 \\
\hline & 39.1 & 18.4 & 42.5 & 100 \\
\hline \multirow{2}{*}{$\begin{array}{l}\text { Q21. Feel more confident about } \\
\text { their work. }\end{array}$} & 41 & 9 & 37 & 87 \\
\hline & 47.1 & $10.4 \dagger$ & 42.5 & 100 \\
\hline \multirow{2}{*}{$\begin{array}{l}\text { Q22. Are anxious about time and } \\
\text { peer pressure. }\end{array}$} & 14 & 7 & 66 & 87 \\
\hline & 16.1 & 8.0 & 75.9 & 100 \\
\hline
\end{tabular}

$\dagger$, Adjusted to give a summation of $100 \%$.

which end up in a trauma (82.8\%) and income which is below the poverty datum line (79.3\%), thus affirmatively confirming Cohen et al.'s (2019) and Legg's (2020) findings on these attributes. Further interrogation on the personal factors led to the admission that teachers who are anxious of time and peer pressure $(75.9 \%)$, are extremely competitive (63.2\%) and power hungry $(51.7 \%)$ were prone to stress. However, there were mixed feelings about those who were confident about their work (47.1), had a strong sense of urgency (42.5\%) and were hostile ( $42.5 \%)$ as noted by the ratings which are below average. On the contrary, they denied that teachers who were always energetic in their work $(75.9 \%)$ and worked steadily and at a relaxed pace $(67.8 \%)$ were affected by stressful conditions at all.

Table 3 reveals that the majority of respondents are stressed by being intimidated, threatened and deadlines set by the top management $(94.5 \%)$, economic problems (92\%), being illtreated by the top management $(90.8 \%)$, uncertainty of job expectations and too many responsibilities $(89.7 \%)$, infrequent rest breaks and long working hours $(87.3 \%)$, high teacher/ learner ratio and routinised tasks (83.9\%), lack of support from the top management $(80.5 \%)$, autocratic leaders $(79.3 \%)$, rapid changes which occur in schools (79.3\%), crowded classrooms $(74.7 \%)$, conforming to standards beyond expectations (73.6\%), poorly equipped classrooms $(72.4 \%)$, lack of opportunity for growth and advancement (63.2\%) and gender stereotypes (58.6\%) in their workplaces. However, they denied that democratic leaders $(71.3 \%)$ and top management who recognise their efforts $(51.7 \%)$ stressed them. 
TABLE 3: Causes of organisational and work-related stress $(n=87)$.

\begin{tabular}{|c|c|c|c|c|}
\hline \multirow[t]{2}{*}{ Frequency table } & \multicolumn{3}{|c|}{ Perception rating } & \multirow[t]{2}{*}{ Total } \\
\hline & D & $U$ & A & \\
\hline \multicolumn{5}{|l|}{$\begin{array}{l}\text { Organisational and work-related } \\
\text { stress is caused by: }\end{array}$} \\
\hline \multirow{2}{*}{$\begin{array}{l}\text { Q23. Lack of opportunity for growth } \\
\text { and advancement in schools. }\end{array}$} & 23 & 9 & 55 & 87 \\
\hline & 26.4 & $10.4 \dagger$ & 63.2 & 100 \\
\hline \multirow{2}{*}{$\begin{array}{l}\text { Q24. Rapid changes which occur } \\
\text { in schools. }\end{array}$} & 11 & 7 & 69 & 87 \\
\hline & 12.6 & $8.1 \dagger$ & 79.3 & 100 \\
\hline \multirow{2}{*}{$\begin{array}{l}\text { Q25. Intimidation, threats and } \\
\text { deadlines by top management. }\end{array}$} & 3 & 1 & 83 & 87 \\
\hline & 3.4 & $1.2 \dagger$ & 95.4 & 100 \\
\hline \multirow{2}{*}{$\begin{array}{l}\text { Q26. High teacher-learner ratios } \\
\text { and routinised tasks. }\end{array}$} & 8 & 6 & 73 & 87 \\
\hline & 9.2 & 6.9 & 83.9 & 100 \\
\hline \multirow{2}{*}{$\begin{array}{l}\text { Q27. Infrequent rest breaks and } \\
\text { long working hours. }\end{array}$} & 8 & 3 & 79 & 87 \\
\hline & 9.2 & $3.5 \dagger$ & 87.3 & 100 \\
\hline \multirow{2}{*}{$\begin{array}{l}\text { Q28. Uncertain job expectations } \\
\text { and too many responsibilities. }\end{array}$} & 4 & 5 & 78 & 87 \\
\hline & 4.6 & 5.7 & 89.7 & 100 \\
\hline \multirow[t]{2}{*}{ Q29. Autocratic leaders. } & 5 & 13 & 69 & 87 \\
\hline & 5.7 & $15.0 \dagger$ & 79.3 & 100 \\
\hline \multirow{2}{*}{$\begin{array}{l}\text { Q30. Conforming to standards } \\
\text { beyond one's expectations. }\end{array}$} & 11 & 12 & 64 & 87 \\
\hline & 12.6 & 13.8 & 73.6 & 100 \\
\hline \multirow[t]{2}{*}{ Q31. Gender stereotypes. } & 29 & 7 & 51 & 87 \\
\hline & 33.3 & 8.1 & 58.6 & 100 \\
\hline \multirow{2}{*}{$\begin{array}{l}\text { Q32. Top management who } \\
\text { recognise the efforts of teachers. }\end{array}$} & 45 & 13 & 29 & 87 \\
\hline & 51.7 & $15.0 \dagger$ & 33.3 & 100 \\
\hline \multirow{2}{*}{$\begin{array}{l}\text { Q33. Being ill-treated by top } \\
\text { management. }\end{array}$} & 6 & 2 & 79 & 87 \\
\hline & 6.9 & 2.3 & 90.8 & 100 \\
\hline \multirow{2}{*}{$\begin{array}{l}\text { Q34. Lacking support from top } \\
\text { management. }\end{array}$} & 6 & 11 & 70 & 87 \\
\hline & 6.9 & 12.6 & 80.5 & 100 \\
\hline \multirow[t]{2}{*}{ Q35. Democratic leaders. } & 62 & 4 & 21 & 87 \\
\hline & 71.3 & 4.6 & 24.1 & 100 \\
\hline \multirow[t]{2}{*}{ Q36. Poorly equipped classrooms. } & 16 & 8 & 63 & 87 \\
\hline & 18.4 & 9.2 & 72.4 & 100 \\
\hline \multirow[t]{2}{*}{ Q37. Crowded classrooms. } & 14 & 8 & 65 & 87 \\
\hline & 16.1 & 9.2 & 72.4 & 100 \\
\hline \multirow[t]{2}{*}{ Q38. Economic problems. } & 4 & 3 & 80 & 87 \\
\hline & 4.6 & 3.4 & 92.0 & 100 \\
\hline
\end{tabular}

$\uparrow$, Adjusted to give a summation of 100 .

Of noteworthy here is that the results of the survey conform and confirm the negative and positive stressors established by the majority of studies cited in this study. However, of major significance to this survey are the radical curricula changes $(79.3 \%)$ that the Zimbabwean government undertook (GoZ, 2015; Ngwenya, 2020), and seem to have triggered most of the stressors prevalent in the educational arena as observed by Kanyongo (2005) and Shizha and Kariwo (2011).

\section{Management of stress}

Having identified the major stressors, it was imperative to establish coping strategies which teachers use when confronted by stressful situations. The results are presented in Table 4.

Table 4 reveals that the majority of respondents managed stress by trying all means to reduce it in whatever way was possible $(90.8 \%)$, sharing stressful experiences with their colleagues $(88.5 \%)$, having planned activities daily $(88.5 \%)$, avoiding overloading oneself with too much work (88.5\%), avoiding conflicting situations (87.4\%), engaging oneself in
TABLE 4: Management of stress $(n=87)$.

\begin{tabular}{|c|c|c|c|c|}
\hline \multirow[t]{2}{*}{ Frequency table } & \multicolumn{3}{|c|}{ Perception rating } & \multirow[t]{2}{*}{ Total } \\
\hline & D & $\mathbf{U}$ & A & \\
\hline \multicolumn{5}{|l|}{ Stress may be managed by: } \\
\hline \multirow{2}{*}{$\begin{array}{l}\text { Q39. Moving away from a } \\
\text { stressful situation. }\end{array}$} & 27 & 9 & 51 & 87 \\
\hline & 31.0 & $10.4 \dagger$ & 58.6 & 100 \\
\hline \multirow{2}{*}{$\begin{array}{l}\text { Q40. Confronting it head-on after } \\
\text { experiencing it. }\end{array}$} & 32 & 8 & 47 & 87 \\
\hline & 36.8 & 9.2 & 54.0 & 100 \\
\hline \multirow{2}{*}{$\begin{array}{l}\text { Q41. Avoiding a stressful } \\
\text { situation. }\end{array}$} & 34 & 15 & 38 & 87 \\
\hline & 39.1 & 17.2 & 43.7 & 100 \\
\hline \multirow{2}{*}{$\begin{array}{l}\text { Q42. Giving up after experiencing } \\
\text { a stressful situation. }\end{array}$} & 61 & 12 & 14 & 87 \\
\hline & 70.1 & 13.8 & 16.1 & 100 \\
\hline \multirow{2}{*}{$\begin{array}{l}\text { Q43. Sharing the stressful } \\
\text { situation with colleagues. }\end{array}$} & 3 & 7 & 77 & 87 \\
\hline & 3.4 & $8.1 \dagger$ & 88.5 & 100 \\
\hline \multirow[t]{2}{*}{ Q44. Planning my daily activities. } & 7 & 3 & 77 & 87 \\
\hline & 8.0 & $3.5 \dagger$ & 88.5 & 100 \\
\hline \multirow{2}{*}{$\begin{array}{l}\text { Q45. Avoiding overloading myself } \\
\text { with too much work. }\end{array}$} & 8 & 2 & 77 & 87 \\
\hline & 9.2 & 2.3 & 88.5 & 100 \\
\hline \multirow{2}{*}{$\begin{array}{l}\text { Q46. Avoiding conflicting } \\
\text { situations. }\end{array}$} & 8 & 3 & 76 & 87 \\
\hline & 9.2 & 3.4 & 87.4 & 100 \\
\hline \multirow{2}{*}{$\begin{array}{l}\text { Q47. Engaging myself in } \\
\text { relaxation activities. }\end{array}$} & 7 & 7 & 73 & 87 \\
\hline & 8.0 & $8.1 \dagger$ & 83.9 & 100 \\
\hline \multirow[t]{2}{*}{ Q48. Taking vacation leave. } & 45 & 13 & 29 & 87 \\
\hline & 51.7 & 15.0 & 33.3 & 100 \\
\hline \multirow{2}{*}{$\begin{array}{l}\text { Q49. Avoiding being pessimistic in } \\
\text { a challenging situation. }\end{array}$} & 18 & 20 & 49 & 87 \\
\hline & 20.7 & 23.0 & 56.3 & 100 \\
\hline \multirow{2}{*}{$\begin{array}{l}\text { Q50. Working harder when my } \\
\text { efforts are recognised. }\end{array}$} & 13 & 4 & 70 & 87 \\
\hline & 14.9 & 4.6 & 80.5 & 100 \\
\hline \multirow{2}{*}{$\begin{array}{l}\text { Q51. Preferring to teach different } \\
\text { grades/classes every year. }\end{array}$} & 50 & 6 & 31 & 87 \\
\hline & 57.5 & 6.9 & 35.6 & 100 \\
\hline \multirow{2}{*}{$\begin{array}{l}\text { Q52. Managing stress in the } \\
\text { manner I have been trained to do. }\end{array}$} & 41 & 7 & 39 & 87 \\
\hline & 47.1 & 8.0 & 44.8 & 100 \\
\hline \multirow{2}{*}{$\begin{array}{l}\text { Q53. Sharing challenges I am } \\
\text { encountering with my mentor. }\end{array}$} & 30 & 14 & 43 & 87 \\
\hline & 34.5 & 16.1 & 49.4 & 100 \\
\hline \multirow{2}{*}{$\begin{array}{l}\text { Q54. Sharing my problems with } \\
\text { the supportive group I belong to. }\end{array}$} & 43 & 4 & 40 & 87 \\
\hline & 49.4 & 4.6 & 46.0 & 100 \\
\hline \multirow[t]{2}{*}{ Q55. Becoming prayerful. } & 8 & 6 & 73 & 87 \\
\hline & 9.2 & 6.9 & 83.9 & 100 \\
\hline \multirow{2}{*}{$\begin{array}{l}\text { Q56. Sharing my stressful } \\
\text { experience with management. }\end{array}$} & 33 & 7 & 47 & 87 \\
\hline & 37.9 & $8.1 \dagger$ & 54.0 & 100 \\
\hline Q57. Trying to reduce my stress & 3 & 5 & 79 & 87 \\
\hline & 3.4 & $5.8 \dagger$ & 90.8 & 100 \\
\hline Q58. Trying to be aware of what & 7 & 7 & 73 & 87 \\
\hline management expects or $n$ & 8.0 & $8.1 \dagger$ & 83.9 & 100 \\
\hline Q59. Avoiding being overzealous & 20 & 13 & 54 & 87 \\
\hline 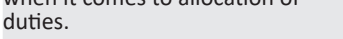 & 23.0 & 14.9 & 62.1 & 100 \\
\hline Q60. Seeking guidance and & 26 & 16 & 45 & 87 \\
\hline $\begin{array}{l}\text { school system. } \\
\text { s. }\end{array}$ & 29.9 & 18.4 & 51.7 & 100 \\
\hline Q61. Engaging management in & 15 & 5 & 67 & 87 \\
\hline ( & 17.2 & 5.8 & 77.0 & 100 \\
\hline
\end{tabular}

$\dagger$, Adjusted to give a summation of 100 .

relaxation activities (83.9\%), becoming prayerful (83.9\%), trying to be aware about the job expectations of the management $(83.9 \%)$, working harder when one's efforts are recognised (80.5\%), engaging management in decisional issues concerning their work $(77.9 \%)$, avoiding being overzealous when duties are being allocated (62.1\%), moving away from a stressful situation (58.6\%), avoiding being pessimistic when confronted with a challenging situation (56.3\%), sharing one's stressful situation with management $(54 \%)$, confronting it head-on $(54 \%)$, and 
seeking guidance and counselling services within the school system $(51.7 \%)$.

Interesting though was the discovery that teachers did not surrender easily when experiencing a stressful situation (70.1\%). Little wonder that they avoided being pessimistic when confronted with a challenging situation (56.3\%). Neither did they prefer to teach the same grade/class regularly (57.5\%). However, surprising was their contradiction that going on vacation leave reduced stress levels (51.7\%) as suggested by Legg (2020) and Tran et al. (2020), yet earlier on they had admitted that relaxation activities did so (83.9\%). Probably their incomes which were below the poverty datum line and the prevailing economic conditions could have influenced their negative response on vacation leave or they might not be aware that relaxation is a part of it.

Conflicting sentiments were also manifested when teachers were required to share stressful experiences with their colleagues $(49.4 \%)$ and manage stress in the manner they were trained (47.1\%). In the absence of a probe, although the ratings are below average, the researcher deduced that for reasons best known to them, teachers investigated did not have faith in their social support groups and doubted whatever stress management training they had undergone.

\section{Discussion}

Generally, BMP primary teachers seem to be conscious of the fact that if overstretched beyond their physical and mental capabilities they are likely to experience emotional breakdown, burnout or distress, stressful conditions which may reduce their creativity, productivity, efficiency and effectiveness if not successfully managed (Haokip \& Latha, 2018; Rosch, 2017; Tran et al., 2020). Besides, if such stressful conditions are prolonged unhindered, the body's immune system may collapse and be put at risk of an avalanche of stress-related illnesses (Legg, 2020; The American Institute of Stress, 2020; Tan \& Yip, 2018). These conditions are of concern to this study, more so that guidance and counselling services and mental hospitals are limited in Zimbabwe as observed by Zvanyanya (2020).

Of significance to this study is that the BMP primary teachers in the investigated schools were able to identify life events, personal and organisational factors which stressed them at their workplaces as suggested by the literature surveyed. It was also encouraging to note that they were aware that a Type A personality was stressful as revealed by their positive ratings on the following attributes: 'power hungry', 'extremely competitive' and 'anxious of time and peer pressure' (cf. Table 2; James \& Sidin, 2017). The existence of such a personality is further confirmed in their admission that teachers who 'have a strong sense of urgency' and 'are hostile' are equally prone to stress, although their ratings are below average. The presence of such attributes in a teacher may be worsened if one is undergoing traumatic experiences which are caused by marital problems, financial difficulties, physical illness or death of a beloved one and the effects of low salaries (cf. Table 2; Cohen et al., 2019; Legg, 2020). Based by these observations, the researcher deduced that the BMP primary teachers are aware of characteristics which constitute a Type A personality which they are supposed to guard against so as to avoid burnout or extreme health effects such as heart attacks in the future as noted by James and Sidin (2017).

Confusing though within this scenario was their refusal that their counterparts who were always energetic in their work were probably stressed as well. Similarly, while recognition of their efforts (cf. Table 3) may make them work harder (cf. Table 4), education managers must guard against demanding expectations beyond their capabilities as this may exert too much pressure on them, thus creating tension and anxiety which are a danger to their well-being as observed by Higuera and Legg (2017).

Pleasing to note is that the BMP primary teachers are capable of repelling stressors of different magnitude emanating from the radical curriculum reforms introduced at postindependence and thereafter (GoZ, 2015) using the stress coping strategies suggested in this study, although they doubted whether they received any form of training in stress management (cf. Table 4). Evidence from the study points out that when confronted by a stressful situation they 'fight or flight' as observed in: 'avoiding conflicting situations', 'engaging management in decisional issues involving work', 'moving away from a stressful situation' and 'confronting it head-on' (cf. Table 4), defence mechanisms needed for their body's survival (Saini, 2016). It was also encouraging to note how they avoided stress by not being 'overzealous when it came to allocation of duties and responsibilities', 'avoiding work-overload' and 'planning their daily' routines - critical and crucial factors in overcoming distress, burnout and exhaustion in their workplace (Juneja, 2015; Legg, 2020).

Based on the unearthed empirical data, the researcher deduced that the majority of the BMP primary teachers are determined at all cost to propel their schools to greater heights in a stress-free environment as long as the job requirements and resources available match their capabilities and needs. Disturbing though was their failure to view vacation leave as a stress reliever and that eustress provided psychological and physical opportunities for learning, growth and achievement. The indication that gender stereotypes are stressors in a workplace populated by women who according to gender studies easily succumb to psychological stress and emotional distress although are more capable of managing stress than their male counterparts is a grey area in need of further investigation (Addison \& Yankyera, 2015; James \& Sidin, 2017; Tran et al., 2020). However, solace may be derived from the fact that the BMP primary teachers are aware of stressors which need management and are likely to trigger an avalanche of stressrelated illnesses, distress, burnout and exhaustion (Haokip \& Latha, 2018; James \& Sidin, 2017; Tran et al., 2020). 


\section{Practical implications and recommendations}

The study is meant to expose teachers to different appropriate coping strategies of recognising stressors at their workplace and manage stress so as to enhance their productivity levels and well-being, including that of the organisation as well. Where stress combating strategies lack, empowerment workshops, courses or seminars may be put in place either at micro or macro level for practising teachers. Furthermore, stress management courses could be offered at tertiary institutions if non-existent. However for female teachers appointed to management posts, more attachment programmes, self-awareness and self-confidence training programmes would be ideal (James \& Sidin, 2017).

Since the study has also revealed that when the job requirements of a teacher exceed one's physical and mental capabilities and expectations, it results in physical or emotional breakdown or exhaustion which are gross symptoms of stress. To avert this dire consequence, the following strategies meant to assist teachers in coping with stressful situations emanating from the workplace may be put in place:

- Teachers must be engaged transparently in decisional issues involving their work.

- Before staffing is done, wide consultations must be made to avoid conflicts with teachers.

- Teachers must be made aware of their stressful working conditions during induction as a way of physically, psychologically, physiologically and emotionally preparing their body for such encounters.

- Tasks assigned must be realistic, challenging and achievable. When teachers have been assigned duties and responsibilities, management must be supportive to their concerns, avail whatever resources are within their capabilities for the fulfilment of such tasks, and stimulate them to attain targets set by using tangible or non-tangible rewards.

- During the execution process, the communication system must be structured in such a way that teachers consult freely without fear or favour.

- Teachers who resemble a Type A personality must be identified and be assisted to execute their jobs in a less stressful way.

Since a problem shared is a problem solved, besides having a professional Guidance and Counselling Unit (GCU) in the school manned by tried and tested teachers with a strong psychological background, teachers must be encouraged to have social groups which they may resort to when faced with traumatic experiences concerning their personal life or professional work. The GCU must be governed by ethical and legal principles with regard to the respect of human dignity, privacy, confidentiality and anonymity, to enable teachers to confidently and faithfully confide their stressful experiences with them. The GCU and social group must also be made aware of how damaging it can be for the teacher or member respectively, when sensitive information about them is released to third parties via the grapevine or various social media platforms.

All things being equal, education managers must create time where they engage with teachers, either as a group or in their gender groups in relaxation exercises, for just about $20 \mathrm{~min}$ perhaps once or twice a week depending upon the need for such sessions. Teachers trained in Physical Education may be utilised to spearhead such sessions or a fitness trainer may be hired for such purposes. Such sessions, if meant to relieve stress, must be informal and be punctuated with jokes here and there. Above all, excursions organised by and for the teachers could be undertaken at least once a year. While their low salaries may be a hindrance, monthly savings and fundraising activities may be introduced for this purpose. Alternatively, sponsorship may be sought from community business people to augment their contributions. Excursions and other social functions and get togethers, which should be organised by teachers, allow them to bond and share their stressful experiences in a relaxed environment away from the hassles of work.

\section{Limitations}

Although the limited sample utilised for this study was homogenous, males were outnumbered by females because of the gender deployment policy which favours the latter. Since gender studies claim that women by their nature are believed to easily succumb to psychological stress and the study was situated in one urban district of BMP out of five, it demands that generalisations to the parent population be made with due care. Furthermore, the use of structured questions and standardised responses did not allow respondents to give their open opinions on the phenomenon under investigation, neither were the probes accommodated for clarification. Therefore, it is recommended that a comparative study be conducted at a macro level with a bigger sample using rigorous statistics to authenticate the results.

\section{Conclusion}

In conclusion, Zimbabwean primary teachers teaching in the BMP seem to be conscious of the different types of stressors present in their professional working environment that are stressful, which provides a fertile ground for equipping them with coping strategies to either remedy or overcome them. Although stress can be a stimulant (i.e. eustress) or a hindrance (i.e. distress), it is the latter which many teachers must guard against because it may be fatal, cause mental, physical and emotional exhaustion which may make the body prone to stress related illnesses of different magnitude. While participative management in the engagement with teachers reduces stress, on the other hand, prolonged negative stress is not only harmful to the teacher but the organisation as well the learners being the net sufferers. Therefore, BMP primary teachers must be trained to recognise stressors in their workplaces earlier on if they are to devise appropriate strategies to successfully manage stress (Legg, 2020). 


\section{Acknowledgements}

The author gratefully acknowledges teachers who were the participants, education managers who are the gatekeepers of the institution, the Ethics Committee, the Permanent Secretary of Education and Provincial Education Director who allowed that the research be conducted in Zimbabwean schools. Finally, the professional editor and the statistician.

\section{Competing interests}

The author is remunerated when the article has been published in an accreditable peer reviewed journal suggested by UNISA College of Economic and Management Sciences.

\section{Author's contributions}

This is my original work of an empirical investigation which I conducted independently and reported on. Works of other researchers have been acknowledged in the appropriate referencing style.

\section{Funding information}

The researcher only receives funding when the article has undergone peer review and published in an accreditable journal suggested by UNISA College of Economic and Management Sciences on behalf of the African Union Agenda 2063 (Personnel No: 90381696).

\section{Data availability}

The article will be available in the public domain for use by other researchers after it has been peer reviewed and published.

\section{Disclaimer}

The views expressed in this article are purely mine and not the official position of the institution or the funder.

\section{References}

Addison, A.K., \& Yankyera, G. (2015). AN investigation into how female teachers manage stress and teacher burnout: A case study of West Akim Municipality in Ghana. Journal of Education and Practice, 6(10), 1-24.

Banister, S. (2007). Ethical issues and qualitative studies in the 21st century: How can digital techniques be embraced in the research community? Journal of Ethnography and Qualitative Research, 1, 1-10.

Best, J.W., \& Khan, J.V. (2014). Research in education (11th ed.). London: Alyn and Beacon.

Bissonnette, V. (2007). Statistical tables. Victor Bissonnette's home page. 23 March 2004. Department of Psychology, Georgia: Berry College.

Cohen, S., Murphy, L.M., \& Prether, A.A. (2019). Ten surprising facts about stressful life events and disease risk. Retrieved from https://www.ncbi.nlm.nih.gov/pmc/ articles/PMC6996482/

Creswell, J.W. (2018). Research design: Qualitative, quantitative and mixed methods approach (4th ed.). London: Sage.

Denzin, N., \& Lincoln, Y.S. (2013). Strategies of qualitative studies. Thousand Oaks, CA: Sage.

Dube, M. (2020, March 17). Deputy Head assaults headmistress. The Chronicle. Retrieved from www.chronicle.co.zw

Government of Zimbabwe (GoZ). (2015). Curriculum framework for primary and secondary education. Harare: Author.

Government of Zimbabwe (GoZ). (2020). Education Amendment Act. Harare: Author.
Gulati, C., \& Parashar, A. (2016). Effort of role stress on job satisfaction in banking sector. In S.S. Bhakkar, C. Gulati, G. Mathur, \& R. Pathak (Eds.), Global advancements in HRM-Innovations and practices (pp. 99-105). New Delhi: Bhat advancements
Publications.

Haokip, T.S., \& Latha, K.L. (2018). A study of stress in management in the workplace. Research Review International Journal of Multidisciplinary. Retrieved from www. rrjournals.com

Health and Safety Executive. (2020). What are the management standards? Retrieved from https://www.hse.gov.uk/stress/standards/

Higuera, V., \& Legg, T.J. (2017). What is general adaptation syndrome? Retrieved from https://www.healthline.com/health/general-adaptation-syndrome

James, K.E., \& Sidin, J.P. (2017). Revisit the effects of type A and B personality, and its effect on job-related stress in the organization. Proceedings of International Conference of Economics, 334-344.

Juneja, P. (2015). Employee stress - Strategies for managing stress at workplace. Retrieved from https://www.managementstudyguide.com/employee-stress.htm

Kanyongo, G. (2005). Zimbabwe's public education system reforms: Successes and challenges. International Education Journal, 6(1), 65-74.

Kaizen Business Coaching. (2021). Goal setting and stress management. Retrieved from https://www.kaizen.zone/management-and-leadership-company-cultureand-mission/goal-setting-and-stress-management/

Legg, T.J. (2017). What to know about general adaptation syndrome? Retrieved from https://www.medicalnewstoday.com/articles/320172

Legg, T.J. (2020). Causes of stress: Recognising and managing your stressors. Retrieved from https://www.healthline.com/health/stress-causes

Lucile, H. (2016). General adaptation syndrome (GAS) stages. Retrieved from https:// www.integrativepro.com/Resources/Integrative-Blog/2016/General-AdaptationSyndrome-Stages

McCombes, S. (2020). Understanding different sampling methods. Retrieved from https://www.scribbr.com/methodology/sampling-methods/

Mujtaba, B.G., Cavico, F.J., \& Senathip, T. (2020). Strategies for personal, organizational and professional leadership success. Scientific Journal of Research and Reviews, 2(3), 1-10. https://doi.org/10.33552/SJRR.2020.02.000538

National Institute for Occupational Safety and Health (NIOSH). (2014). Stress ...at work. Centre for Disease Control and Prevention. Retrieved from https://www. cdc.gov/niosh/docs/99-101/default.html

Ngwenya, V.C. (2020). Curriculum implementation challenges encountered by primary school teachers in Bulawayo Metropolitan Province, Zimbabwe. Africa Education Review, 17(2), 158-176.

Ngwenya, V.C. (2021). Job performance: Working conditions of urban teachers in Zimbabwean schools. SA Journal of Human Resource Management, 19(0), a1454. https://doi.org/10.4102/sajhrm.v19i0.1549

Ngwenya, V.C., \& Pretorius, S.G. (2013). The legal framework governing parental involvement with education in Zimbabwe. Kamla-Raj J Soc Sci, 34(2), 135-144.

O'leary, Z. (2014). The essential guide to doing research. London: Sage.

Panigrahi, A. (2017). Managing stress at workplace. Journal of Management Research and Analysis, 3(4), 154-160. https://doi.org/10.18231/2394-2770.2016.0001

Pelser, A.M.F., \& Van Wyke, C. (2016). Teacher participation in stress management: Through different Theoretical lenses; A study conducted in Mahikeng Area. International Journal Education Research, 12(1), 1-15. https://doi.org/10.19030/ jier.v12i1.9562

Rosch, P.J. (2017). Reminiscences of Hans Selye, and the birth of 'Stress'. American Institute of Stress. Retrieved from https://www.stress.org/about/hans-selyebirth-of-stress

Saini, A. (2016). Effort of role stress on job satisfaction in banking sector. In S.S Bhakkar, C. Gulati, G. Mathur, \& R. Pathak (Eds.), Global advancements in HRM Innovations and practices (pp. 265-276). New Delhi: Bhati Publications.

Satpathy, I., \& Mitra, B. (2015). Stress management policies by IT companies - An overview. Retrieved from researchgate.net

Schmidt, M.V., \& Chen, A. (2021). Frontiers of stress research: The 2nd Munich Winter conference on stress. The International Journal on the Biology of Stress, 24(2), 121-122. https://doi.org/10.1080/10253890.2021.1895937

Sharma, G. (2017). Pros and cons of different sampling techniques. Internal Journal of Applied Science, 3(17), 749-752.

Shizha, E., \& Kariwo, M.T. (2011). Education and development in Zimbabwe: A social, political and economic analysis. Rotterdam: Sense Publishers.

Selye, H. (1936). A Syndrome produced by diverse nocuous agents. Nature, 138, 32. https://doi.org/10.1038/138032a0

Sibanda, L., \& Young, J. (2020). Towards a postcolonial curriculum in Zimbabwe: A critical review of literature. Africa Education Review, 17(2), 50-72. https://doi.org /10.1080/18146627.2018.1507622

Tan, S.Y., \& Yip, A. (2018). Hans Selye (1907-1982): Founder of the stress theory. Singapore Medical Journal, 59(4), 170-171. https://doi.org/10.11622/smedj.2018043

The American Institute of Stress. (2020). How stress affects your body? Retrieved from https://www.stress.org/how-stress-sffects-your-body

Tran, C.T.H., Tran, H.T.M., Nguyen, H.T.N., Mach, D.N., Phen, H.S.P., \& Mujtaba, B.G. (2020). Stress management in the modern workplace and the role of human resource professionals. Business Ethics and Leadership, 4(2), 26-40. https://doi. org/10.21272/bel.4(2).26-40.2020

Zvanyanya, M. (2020, March 2). 100000 seek help for depression and anxiety. The Chronicle. Retrieved from www.chronicle.co.zw 